\title{
LEVEL II SCOUR ANALYSIS FOR BRIDGE 46 (NORWTH00030046) on TOWN HIGHWAY 3 (VT132), crossing the OMPOMPANOOSUC RIVER, NORWICH, VERMONT
}

U.S. Geological Survey Open-File Report 96-160

Prepared in cooperation with

VERMONT AGENCY OF TRANSPORTATION and

FEDERAL HIGHWAY ADMINISTRATION 


\section{LEVEL II SCOUR ANALYSIS FOR BRIDGE 46 (NORWTH00030046) on TOWN HIGHWAY 3 (VT132), crossing the OMPOMPANOOSUC RIVER, NORWICH, VERMONT \\ By SCOTT A. OLSON and DONALD L. SONG}

U.S. Geological Survey Open-File Report 96-160

Prepared in cooperation with

VERMONT AGENCY OF TRANSPORTATION and

FEDERAL HIGHWAY ADMINISTRATION 


\title{
U.S. DEPARTMENT OF THE INTERIOR BRUCE BABBITT, Secretary
}

\author{
U.S. GEOLOGICAL SURVEY \\ Gordon P. Eaton, Director
}

For additional information write to:

District Chief

U.S. Geological Survey 361 Commerce Way

Pembroke, NH 03275-3718
Copies of this report may be purchased from:

U.S. Geological Survey Earth Science Information Center Open-File Reports Section Box 25286, MS 517 Federal Center

Denver, CO 80225 


\section{CONTENTS}

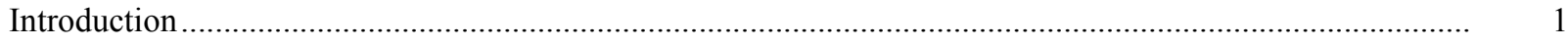

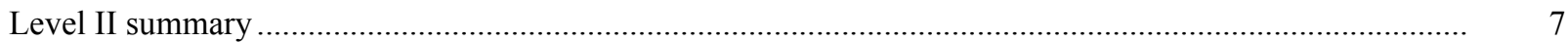

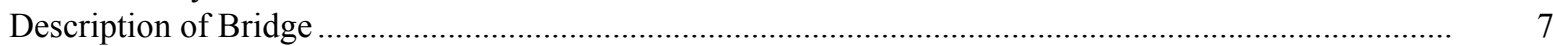

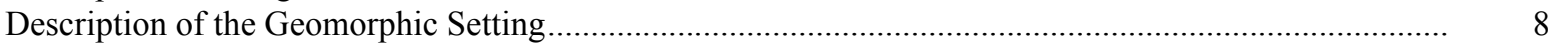

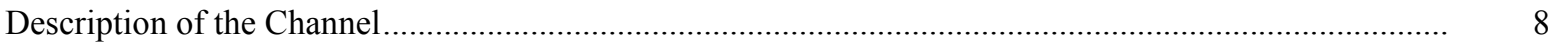

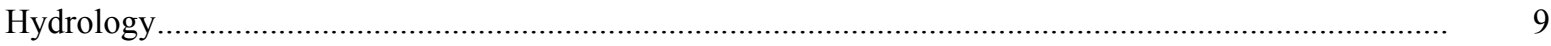

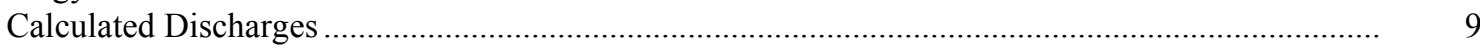

Description of the Water-Surface Profile Model (WSPRO) Analysis ......................................................... 10

Cross-Sections Used in WSPRO Analysis ......................................................................................

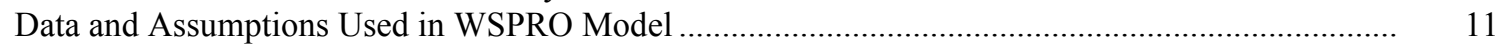

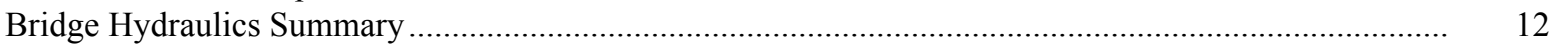

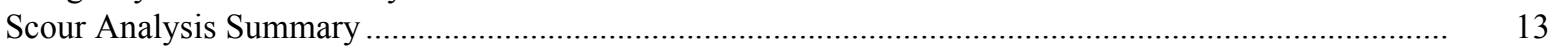

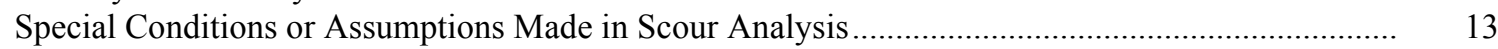

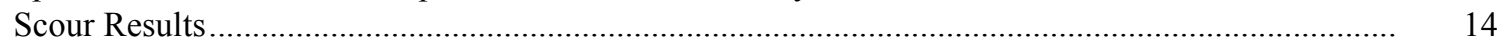

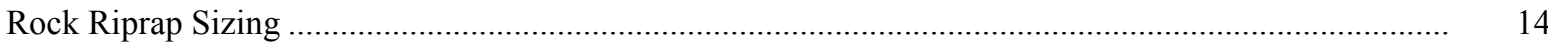

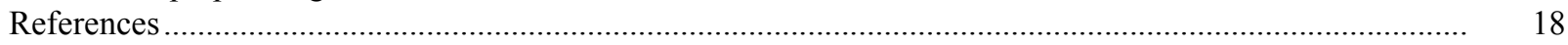

Appendixes:

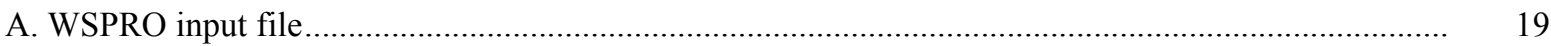

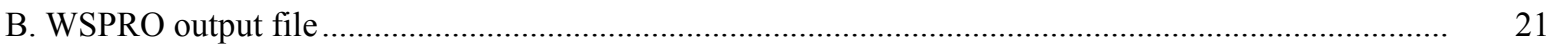

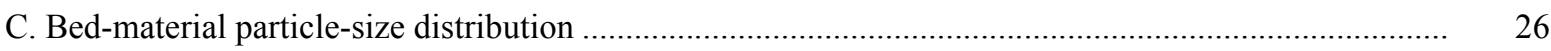

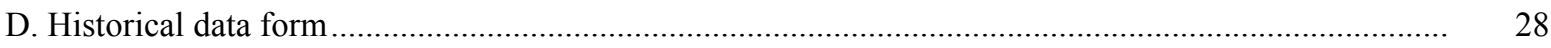

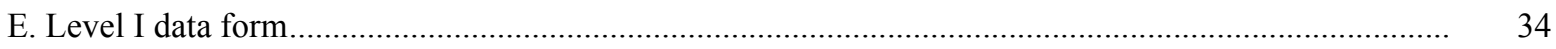

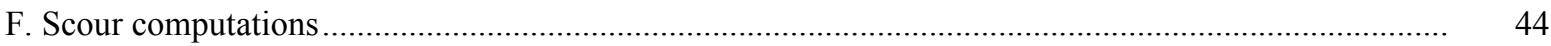

\section{FIGURES}

1. Map showing location of study area on USGS $1: 24,000$ scale map .......................................................

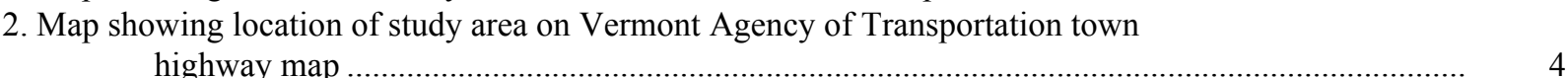

3. Structure NORWTH00030046 viewed from upstream (April 20, 1995) ….................................................... 5

4. Upstream channel viewed from structure NORWTH00030046 (August 19, 1994)................................... 5

5. Downstream channel viewed from structure NORWTH00030046 (August 19, 1994)................................ 6

6. Structure NORWTH00030046 viewed from downstream (April 20, 1995). ............................................ 6

7. Water-surface profiles for the 100- and 500-year discharges at structure

NORWTH00030046 on Town Highway 3, crossingthe Ompompanoosuc River,

Norwich, Vermont.

8. Scour elevations for the 100 - and 500-year discharges at structure

NORWTH00030046 on Town Highway 3, crossing the Ompompanoosuc River,

Norwich, Vermont

\section{TABLES}

1. Remaining footing/pile depth at abutments for the 100-year discharge at structure

NORWTH00030046 on Town Highway 3, crossing the Ompompanoosuc River,

Norwich, Vermont

2. Remaining footing/pile depth at abutments for the 500-year discharge at structure

NORWTH00030046 on Town Highway 3, crossing the Ompompanoosuc River,

Norwich, Vermont 


\begin{tabular}{|c|c|c|}
\hline Multiply & By & To obtain \\
\hline \multicolumn{3}{|c|}{ Length } \\
\hline inch (in.) & 25.4 & millimeter (mm) \\
\hline foot $(\mathrm{ft})$ & 0.3048 & meter $(\mathrm{m})$ \\
\hline mile (mi) & 1.609 & kilometer (km) \\
\hline \multicolumn{3}{|c|}{ Slope } \\
\hline foot per mile ( $\mathrm{ft} / \mathrm{mi})$ & 0.1894 & meter per kilometer $(\mathrm{m} / \mathrm{km})$ \\
\hline \multicolumn{3}{|c|}{ Area } \\
\hline square mile $\left(\mathrm{mi}^{2}\right)$ & 2.590 & square kilometer $\left(\mathrm{km}^{2}\right)$ \\
\hline \multicolumn{3}{|c|}{ Volume } \\
\hline cubic foot $\left(\mathrm{ft}^{3}\right)$ & $\begin{array}{l}0.02832 \\
\text { Velocity and Flow }\end{array}$ & cubic meter $\left(\mathrm{m}^{3}\right)$ \\
\hline foot per second (ft/s) & 0.3048 & meter per second $(\mathrm{m} / \mathrm{s})$ \\
\hline cubic foot per second $\left(\mathrm{ft}^{3} / \mathrm{s}\right)$ & 0.02832 & cubic meter per second $\left(\mathrm{m}^{3} / \mathrm{s}\right)$ \\
\hline $\begin{array}{l}\text { cubic foot per second per } \\
\text { square mile } \\
{\left[\left(\mathrm{ft}^{3} / \mathrm{s}\right) / \mathrm{mi}^{2}\right]}\end{array}$ & 0.01093 & $\begin{array}{l}\text { cubic meter per } \\
\text { second per square } \\
\text { kilometer }\left[\left(\mathrm{m}^{3} / \mathrm{s}\right) / \mathrm{km}^{2}\right]\end{array}$ \\
\hline
\end{tabular}

OTHER ABBREVIATIONS

$\begin{array}{lrlr}\mathrm{BF} & \text { bank full } & \text { LWW } & \text { left wingwall } \\ \mathrm{cfs} & \text { cubic feet per second } & \text { MC } & \text { main channel } \\ \mathrm{D}_{50} & \text { median diameter of bed material } & \text { RAB } & \text { right abutment } \\ \mathrm{DS} & \text { downstream } & \text { RABUT } & \text { face of right abutment } \\ \mathrm{elev} & \text { elevation } & \text { RB } & \text { right bank } \\ \mathrm{f} / \mathrm{p} & \text { flood plain } & \text { ROB } & \text { right overbank } \\ \mathrm{ft} & \text { square feet } & \text { RWW } & \text { right wingwall } \\ \mathrm{ft} / \mathrm{ft} & \text { feet per foot } & \text { TH } & \text { town highway } \\ \mathrm{JCT} & \text { junction } & \text { UB } & \text { under bridge } \\ \mathrm{LAB} & \text { left abutment } & \text { US } & \text { upstream } \\ \mathrm{LABUT} & \text { face of left abutment } & \text { USGS } & \text { United States Geological Survey } \\ \text { LB } & \text { left bank } & \text { VTAOT Vermont Agency of Transportation } \\ \text { LOB } & \text { left overbank } & \text { WSPRO } & \text { water-surface profile model }\end{array}$

In this report, the words "right" and "left" refer to directions that would be reported by an observer facing downstream. Sea level: In this report, "sea level" refers to the National Geodetic Vertical Datum of 1929-- a geodetic datum derived from a general adjustment of the first-order level nets of the United States and Canada, formerly called Sea Level Datum of 1929.

In the appendices, the above abbreviations may be combined. For example, USLB would represent upstream left bank. 


\title{
LEVEL II SCOUR ANALYSIS FOR BRIDGE 46 (NORWTH00030046) ON TOWN HIGHWAY 3 (VT132), CROSSING THE OMPOMPANOOSUC RIVER, NORWICH, VERMONT
}

\author{
By Scott A. Olson and Donald L. Song
}

\section{INTRODUCTION}

This report provides the results of a detailed Level II analysis of scour potential at structure NORWTH00030046 on town highway 3, which is also Vermont State Route 132 crossing the Ompompanoosuc River, Norwich, Vermont (figures 1-8). A Level II study is a basic engineering analysis of the site, including a quantitative analysis of stream stability and scour (U.S. Department of Transportation, 1993). A Level I study is included in Appendix E of this report. A Level I study provides a qualitative geomorphic characterization of the study site. Information on the bridge, available from VTAOT files, was compiled prior to conducting Level I and Level II analyses and can be found in Appendix D.

The site is in the New England Upland physiographic province of east-central Vermont. The $135-\mathrm{mi}^{2}$ drainage area is a predominantly rural basin. A flood-control reservoir located approximately $2 \mathrm{mi}$ upstream has 1.66 billion cubic feet of usable storage. In the vicinity of the study site, the left bank is forested and the right bank is covered by shrubs and brush, adjacent to woods. The Ompompanoosuc River is parallel to Town Highway 3.

In the study area, the Ompompanoosuc River has a sinuous channel with a slope of approximately $0.003 \mathrm{ft} / \mathrm{ft}$, an average channel top width of $166 \mathrm{ft}$ and an average channel depth of $6 \mathrm{ft}$. The predominant channel bed material is sand $\left(\mathrm{D}_{50}\right.$ is $0.744 \mathrm{~mm}$ or 0.00244 $\mathrm{ft})$. The geomorphic assessment at the time of the Level I and Level II site visit on August 19, 1994, indicated that the reach was stable. 
The town highway 3 crossing of the Ompompanoosuc River is a 100-ft-long, two-lane bridge consisting of two steel-beam spans (Vermont Agency of Transportation, written commun., July 29, 1994). The bridge is supported by vertical, concrete abutments with wingwalls. The channel is skewed approximately 25 degrees to the opening while the opening-skew-to-roadway is 12 degrees. Additional details describing conditions at the site are included in the Level II Summary and Appendices D and $\mathrm{E}$.

Scour depths and rock rip-rap sizes were computed using the general guidelines described in Hydraulic Engineering Circular 18 (Richardson and others, 1993). Scour depths were calculated assuming an infinite depth of erosive material and a homogeneous particle-size distribution. The scour analysis results are presented in tables 1 and 2 and a graph of the scour depths is presented in figure 8 . 


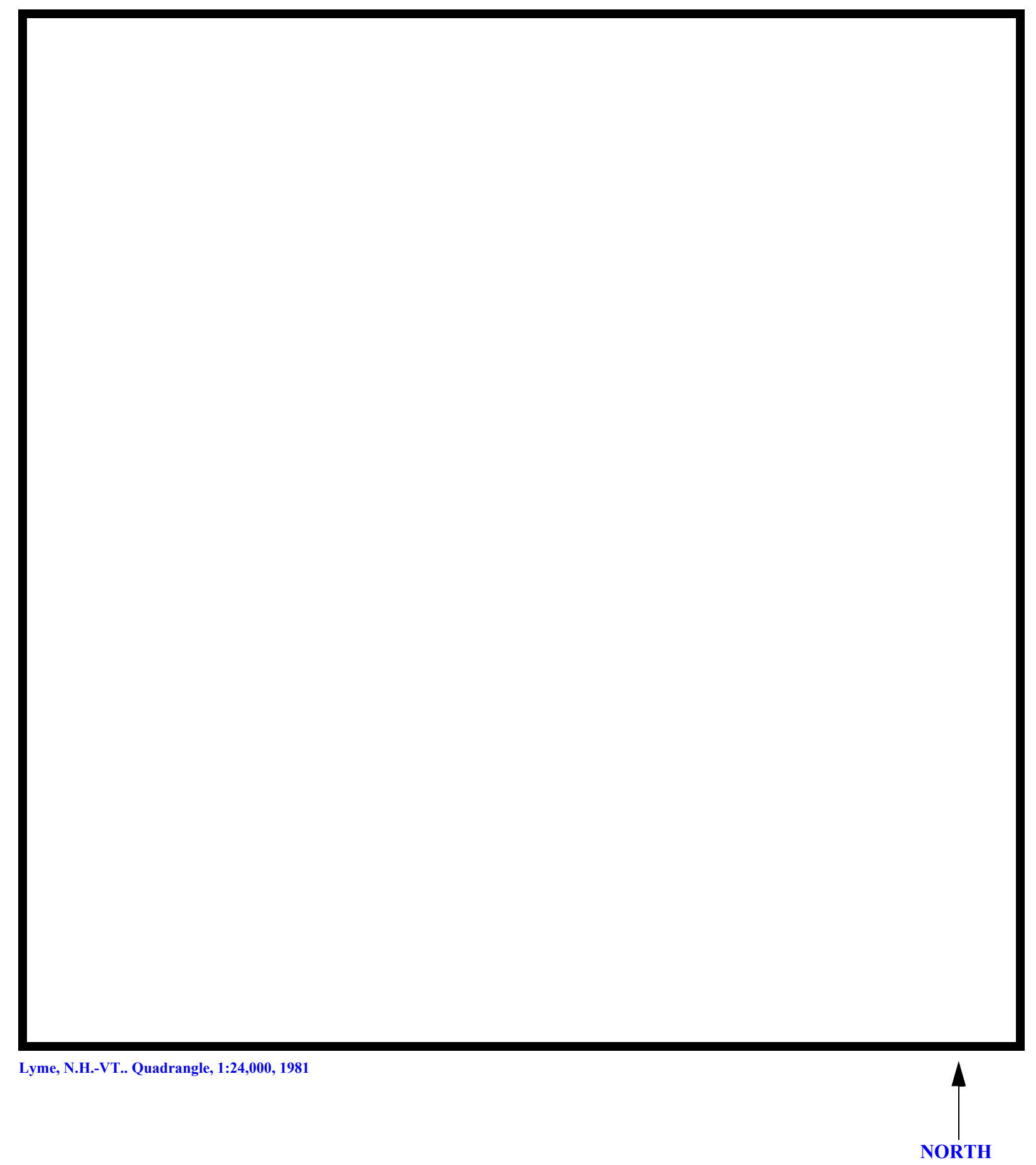

Figure 1. Location of study area on USGS 1:24,000 scale map. 
Figure 2. Location of study area on Vermont Agency of Transportation town highway map. 

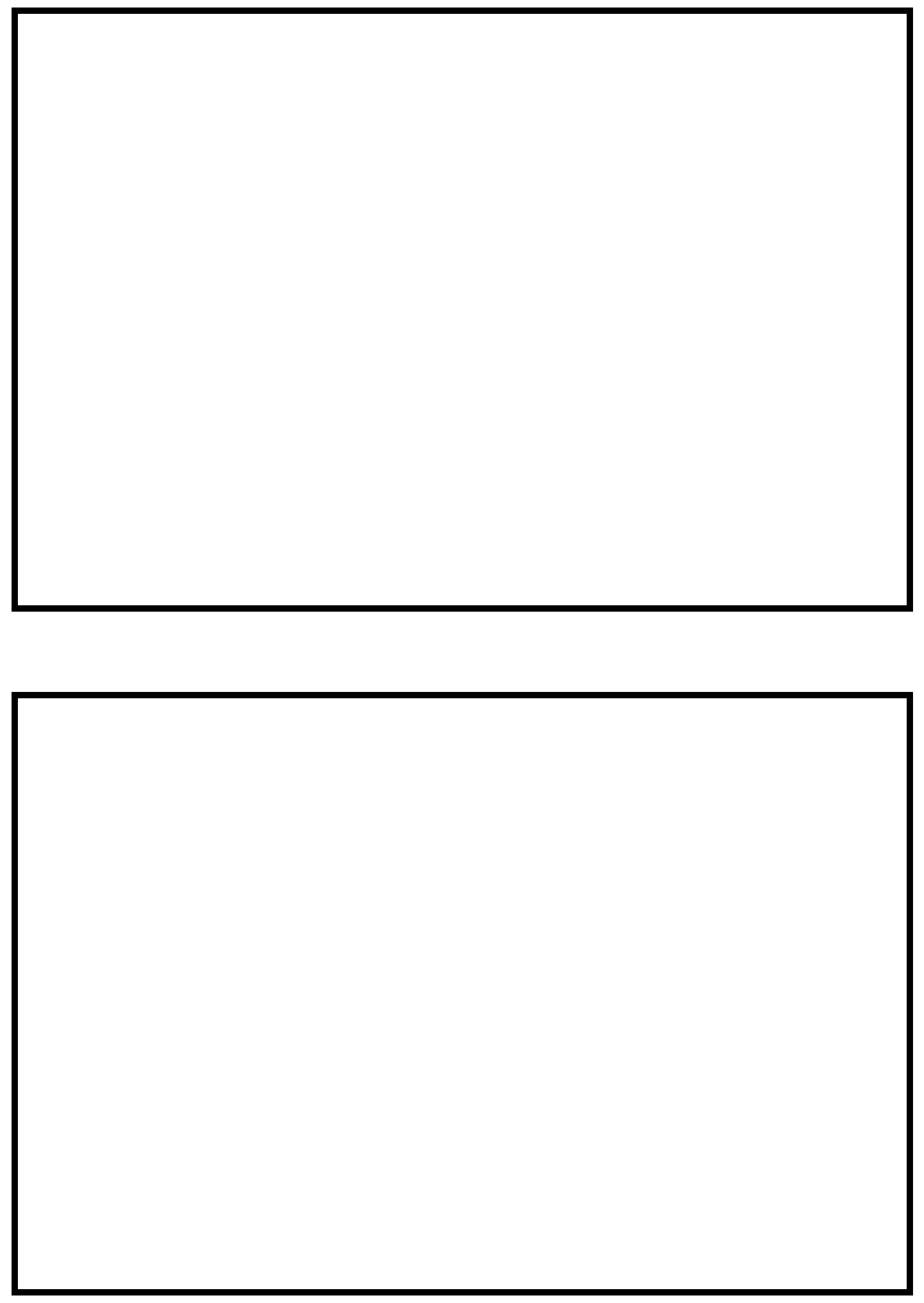

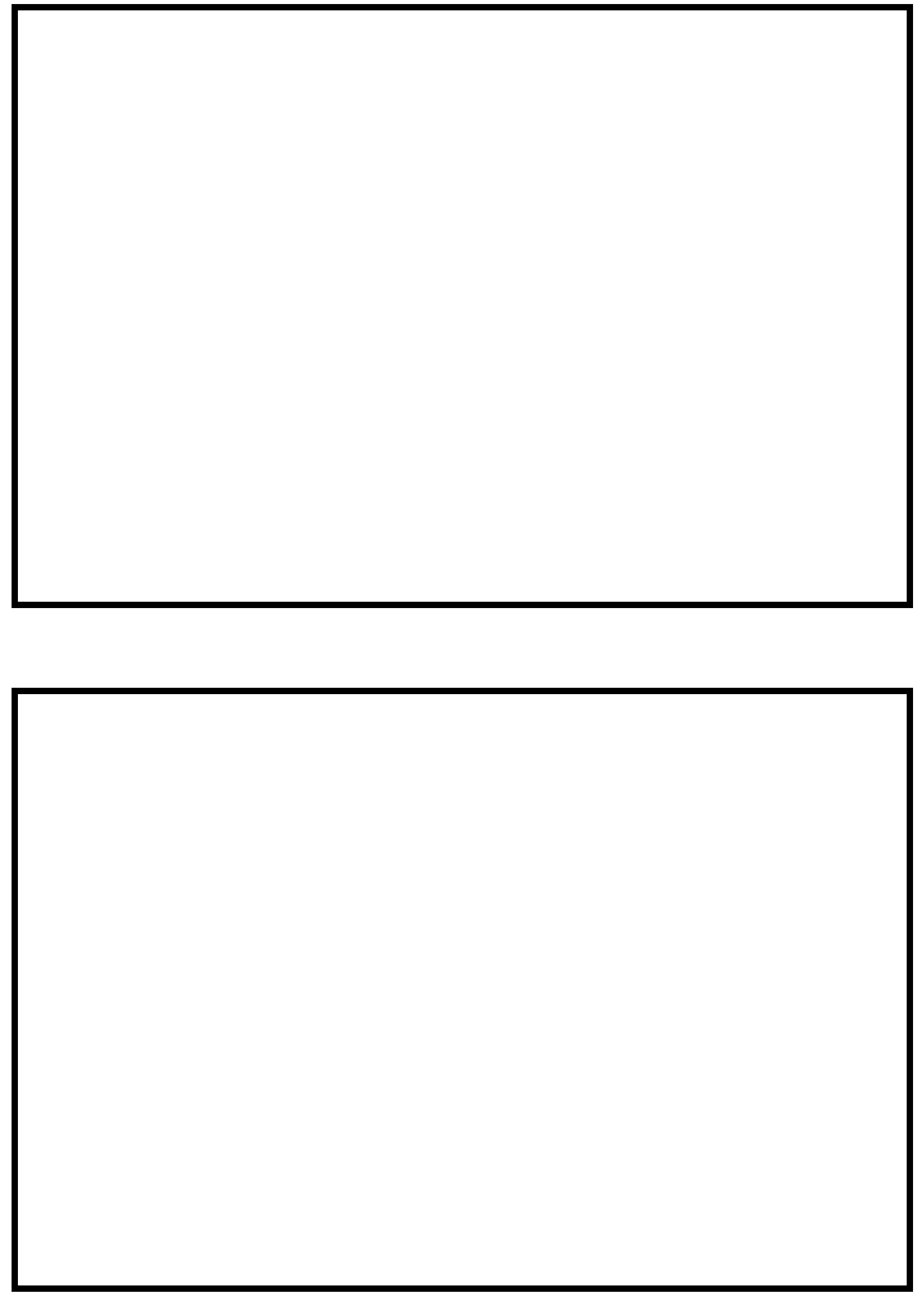


\section{LEVEL II SUMMARY}

\begin{tabular}{lccccc}
\multirow{2}{*}{ Structure Number } & NORWTH00030046 & Stream & \multicolumn{2}{c}{ Ompompanoosuc River } \\
\cline { 2 - 2 } County & Road & TH003 & District & 04 \\
\hline
\end{tabular}

\section{Description of Bridge}

Bridge length $\frac{100}{f t}$ Bridge width $\frac{27.5}{f t}$ Max span length $\frac{47}{f t}$ Alignment of bridge to road (on curve or straight) Concrete, vertical

Abutment type

Left only

Embankment type Both approaches curve sharply

Stone fill on abutment?

Dato of incnortinn

sloping

nananimsinn af atan s fill

Type-2 stone fill protects the left and right US road approaches and US and DS right wingwalls. Type-1 protection was noted at the left abutment and US left wingwall.

No protection existed at the right abutment and DS left wingwall.

Piers and abutments are concrete. Footings of both the

pier and abutments are exposed.

Yes

Is bridge skewed to flood flow according to № r survey? Angle

25

Is bridge skewed to flood flow according to № r survey? Angle

Debris accumulation on bridge at time of Level I or Level II site visit:

\begin{tabular}{|c|c|c|c|}
\hline & $\begin{array}{c}\text { Dato of insnortion } \\
08 / 19 \text { and } 12 / 07 / 94\end{array}$ & $\begin{array}{l}\text { Percent of a smunal } \\
\text { blocked hortzontatly }\end{array}$ & $\begin{array}{l}\text { Percent }_{0}^{f} \\
\text { blocked verticatty }\end{array}$ \\
\hline Level I & 08/19/94 & 0 & 0 \\
\hline $\begin{array}{l}\text { Level II } \\
\text { upstream. }\end{array}$ & \multicolumn{3}{|c|}{ Low due to fairly stable banks and the flood control reservoir } \\
\hline
\end{tabular}

There is a flood control reservoir about two miles upstream of bridge site. About 3/4 mile Doscriho any foaturos noar ar at tho hridoo that mav' affoct flow, (includo ahsorvation dato). downstream is the Connecticut River. There is backwater from the Connecticut River at the bridge site. 


\section{Description of the Geomorphic Setting}

General topography The site is in a moderate relief valley with a narrow flood plain. The immediate reach is incised.

Geomorphic conditions at bridge site: downstream (DS), upstream (US)

Date of inspection $\quad 12 / 07 / 94$

DS left: $\quad$ Steep river bank with a flat overbank. State Highway 132 parallels river.

DS right: $\quad$ Moderately steep valley wall.

US left: $\quad$ Flat and low with some swampy areas.

US right: $\quad$ Moderately steep valley wall. State Highway 132 parallels river.

\section{Description of the Channel}

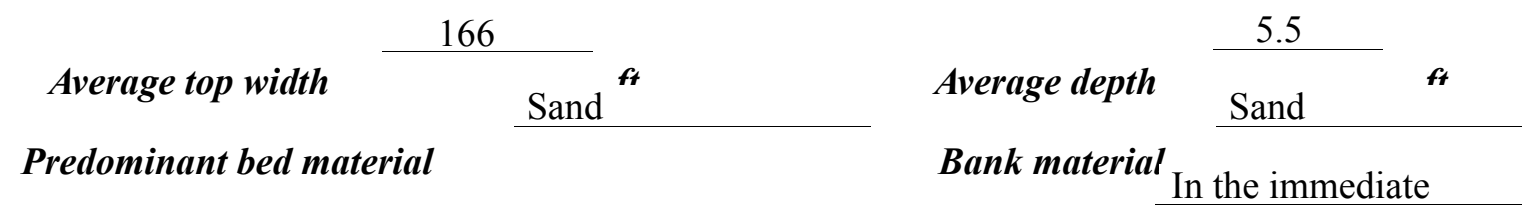

vicinity it is a straight channel. Further upstream it is a meandering channel.

Vegetative co ${ }^{1}$ Brush and grass. State Highway 132 parallels river.

DS left: $\quad$ Brush.

DS right: $\quad$ Trees and thick brush.

US left: $\quad$ Brush and grass. State Highway 132 parallels river.

US right: $\quad$ Yes

Do banks appear stable? None.

date of observatton.

None

Describe any obstructions in channel and date of observation. 


\section{Hydrology}

Drainage area $\frac{135}{\boldsymbol{m i}^{2}}$

Percentage of drainage area in physiographic provinces: (approximate)

Physiographic province New England Upland
Percent of drainage area 100

Is drainage area considered rural or urban?

Rural urbanization: None

Describe any significant

Is there a USGS gage on the stream of interest? USGS gage description Ompompanoosuc River at Union Village

\section{USGS gage number}

Gage drainage area $\mathrm{mi}^{2}$
Yes

Is there a lake/p The Union Village Reservoir has a capacity of 1.66 billion cubic feet, significantly affecting the hydrology at this site.

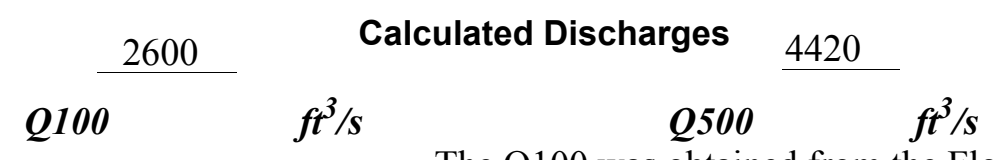
The Q100 was obtained from the Flood Insurance

Study for the Town of Norwich_(Federal Emergency Management Agency, 1988). The Q500 was determined by multiplying the Q100 by 1.7 (Richardson and others, 1983) 


\section{Description of the Water-Surface Profile Model (WSPRO) Analysis}

Datum for WSPRO analysis (USGS survey, sea level, VTAOT plans)

USGS Survey

Datum tie between USGS survey and VTAOT plans

Subtract 101.20 feet from

surveyed datum to obtain VTAOT datum

Description of reference marks used to determine USGS datum. $\quad$ RM1 is a chiseled

square on top of the DS left wingwall where it meets the left abutment with an arbitrary survey elevation of 500.80 feet.

\section{Cross-Sections Used in WSPRO Analysis}

\begin{tabular}{cccl}
\hline${ }^{1}$ Cross-section & $\begin{array}{c}\text { Section } \\
\text { Reference } \\
\text { Distance } \\
\text { (SRD) in feet }\end{array}$ & $\begin{array}{c}{ }^{2} \text { Cross-section } \\
\text { development }\end{array}$ & \multicolumn{1}{c}{ Comments } \\
\hline EXIT & 0 & 1 & $\begin{array}{l}\text { Exit section } \\
\text { Downstream Full-valley } \\
\text { section (Templated from } \\
\text { FV }\end{array}$ \\
EXITX) \\
BRO & 93 & 2 & Bridge section \\
RD & 107 & 1 & Road Grade section \\
APPR & 288 & 1 & Approach section \\
\hline
\end{tabular}

${ }^{1}$ For location of cross-sections see plan-view sketch included with Level I field form, Appendix E. For more detail on how cross-sections were developed see WSPRO input file. 


\section{Data and Assumptions Used in WSPRO Model}

Hydraulic analyses of the reach were done by use of the Federal Highway Administration's WSPRO step-backwater computer program (Shearman and others, 1986, and

Shearman, 1990). Results of the hydraulic model are presented in the Bridge Hydraulic Summary, Appendix B, and figure 7.

Channel roughness factors (Manning's " $\mathrm{n}$ ") used in the hydraulic model were estimated using field inspections at each cross section following the general guidelines described by Arcement, Jr. and Schneider (1989). Final adjustments to the values were made during the modelling of the reach. Channel " $\mathrm{n}$ " values for the reach ranged from 0.034 to 0.042 , and overbank " $\mathrm{n}$ " values ranged from 0.085 to 0.090 .

The Connecticut River is downstream of the bridge site about 0.75 miles and causes backwater at this bridge. However, the worst-case scenario was modelled for the scour analysis which is to assume the lowest potential downstream water surface elevation (Richardson and others, 1983). Thus, normal depth was assumed as the starting water surface at the exit section (EXIT). This depth was computed by use of the slope-conveyance method outlined in the User's manual for WSPRO (Shearman, 1990). The slope used was $0.003 \mathrm{ft} / \mathrm{ft}$ which was determined from the river-bed profile of the Ompompanoosuc River in the Flood Insurance Study for the Town of Norwich (Federal Emergency Management Agency, 1988).

The surveyed approach section (APPR) was within one bridge length upstream of the upstream face as recommended by Shearman and others (1986). This also provides a consistent method for determining scour variables. 


\section{Bridge Hydraulics Summary}

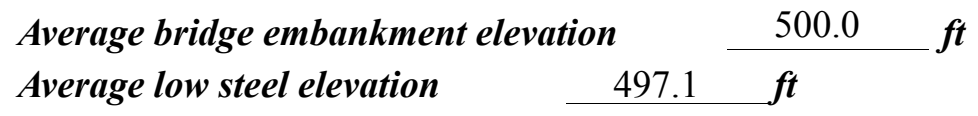

100-year discharge $2600 \quad \mathrm{ft}^{3} / \mathrm{s}$

Water-surface elevation in bridge opening $\quad \begin{aligned} & 484.8 \quad f t \\ & \end{aligned}$

Road overtopping? ___ No Discharge over road ___ _ , is

Area of flow in bridge opening $\quad 378 \quad \mathrm{ft}^{2}$

Average velocity in bridge opening $\quad \begin{array}{lll}6.9 & \mathrm{ft} / \mathrm{s}\end{array}$

$\begin{array}{llll}\text { Maximum WSPRO tube velocity at bridge } & 8.1 \mathrm{ft} / \mathrm{s}\end{array}$

Water-surface elevation at Approach section with bridge 485.8

Water-surface elevation at Approach section without bridge $\quad 485.5$

Amount of backwater caused by bridge $\quad 0.3$ it

500-year discharge $\quad 4420 \quad \mathrm{ft}^{3} / \mathrm{s}$

Water-surface elevation in bridge opening $\quad 485.9 \mathrm{ft}$

Road overtopping? ___ No Discharge over road ___

Area of flow in bridge opening $\quad 471 \quad \mathrm{ft}^{2}$

Average velocity in bridge opening $\quad 9.4 \mathrm{ft} / \mathrm{s}$

Maximum WSPRO tube velocity at bridge $\quad 10.8 \_$'s

Water-surface elevation at Approach section with bridge 487.6

Water-surface elevation at Approach section without bridge $\quad 487.0$

Amount of backwater caused by bridge 0.6 .

Incipient overtopping discharge ___ _- $\mathrm{ft}^{3} / \mathrm{s}$

Water-surface elevation in bridge opening $\quad--\quad t$

Area of flow in bridge opening _ -- $\mathrm{ft}^{2}$

Average velocity in bridge opening __ $\quad--\quad f t / s$

Maximum WSPRO tube velocity at bridge $\quad--\quad f t / s$

Water-surface elevation at Approach section with bridge

Water-surface elevation at Approach section without bridge

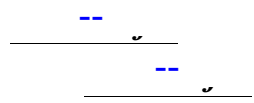

Amount of backwater caused by bridge _ 


\section{Scour Analysis Summary}

\section{Special Conditions or Assumptions Made in Scour Analysis}

Scour depths were computed using the general guidelines described in Hydraulic Engineering Circular 18 (Richardson and others, 1993). Scour depths were calculated assuming an infinite depth of erosive material and a homogeneous particle-size distribution. The results of the scour analysis are presented in tables 1 and 2 and a graph of the scour depths is presented in figure 8.

Contraction scour was computed by use of the live-bed contraction scour equation (Richardson and others, 1993, p. 33, equation 16). For contraction scour computations, the average depth in the contracted section (AREA/TOPWIDTH) is subtracted from the depth of flow computed by the scour equation (Y2) to determine the actual amount of scour.

Abutment scour for the right abutment was computed by use of the Froehlich equation (Richardson and others, 1993, p. 49, equation 24). The Froehlich equation gives "excessively conservative estimates of scour depths" (Richardson and others, 1993, p. 48). Scour at the left abutment was computed by use of the HIRE equation (Richardson and others, 1993, p. 50, equation 25) because the HIRE equation is recommended when the length to depth ratio of the embankment blocking flow exceeds 25. Variables for the abutment scour equations equations include the Froude number of the flow approaching the embankments, the length of the embankment blocking flow, and the depth of flow approaching the embankment less any roadway overtopping.

Pier scour was computed by use of the Colorado State University pier scour equation (Richardson and others, 1993, p.39, equation 21).

Observed thalweg depths during site inspections were noted to be as much as 1.4 feet below the bottom of the abutment footings. Although abutments were not undermined, a lateral shift in the thalweg may be of concern.

The pier footing elevation as designed, according to the bridge plans at VTAOT, is 369.2 feet (470.4 feet field survey datum). The plans also indicate that the pier footing is 2.5 feet thick vertically. The plans also indicate that the footer should be placed on bedrock if bedrock was reached above 369.2 feet. The pier may set on bedrock since the top of the footer is at 377.5 feet ( 478.7 feet field survey datum) and the bottom of the footer, if its 2.5 feet thick, is at 375.0 feet. No additional information was available. 


\section{Scour Results}

$$
\text { 100-yr discharge 500-yr discharge }
$$

(Scour depths in feet)

Main channel

Live-bed scour

Clear-water scour

Depth to armoring

Left overbank

Right overbank

Local scour:

Abutment scour

Left abutment

Right abutment

Pier scour

Pier 1

Pier 2

Pier 3
3.3

$9.7-$

13.0

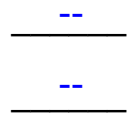

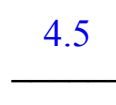

$--$

$--$

$--$

$--$

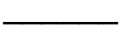
discharge 


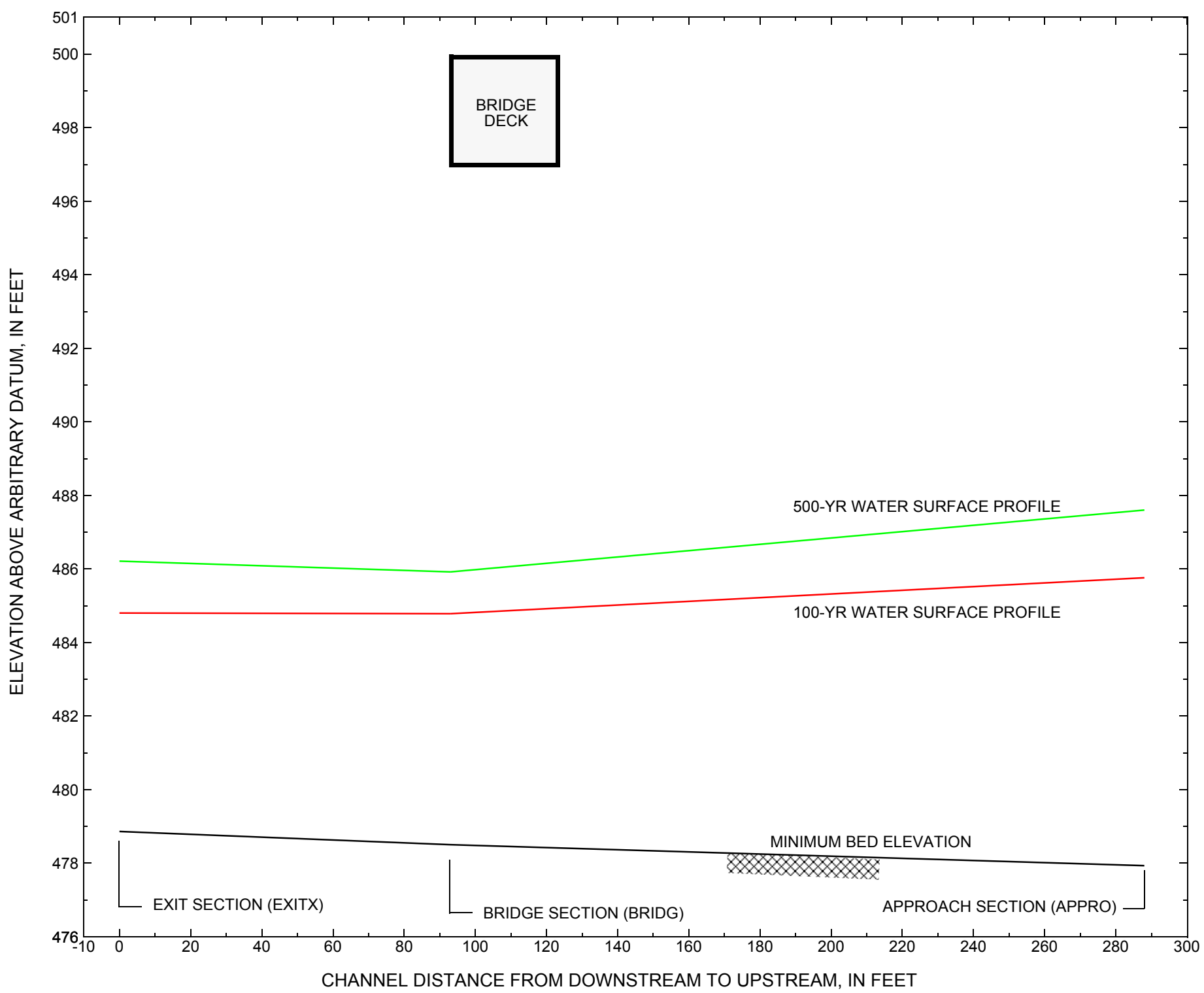

Figure 7. Water-surface profiles for the 100- and 500-yr discharges at structure NORWTH00030046 on town highway 3, crossing the Ompompanoosuc River, Norwich, Vermont. 


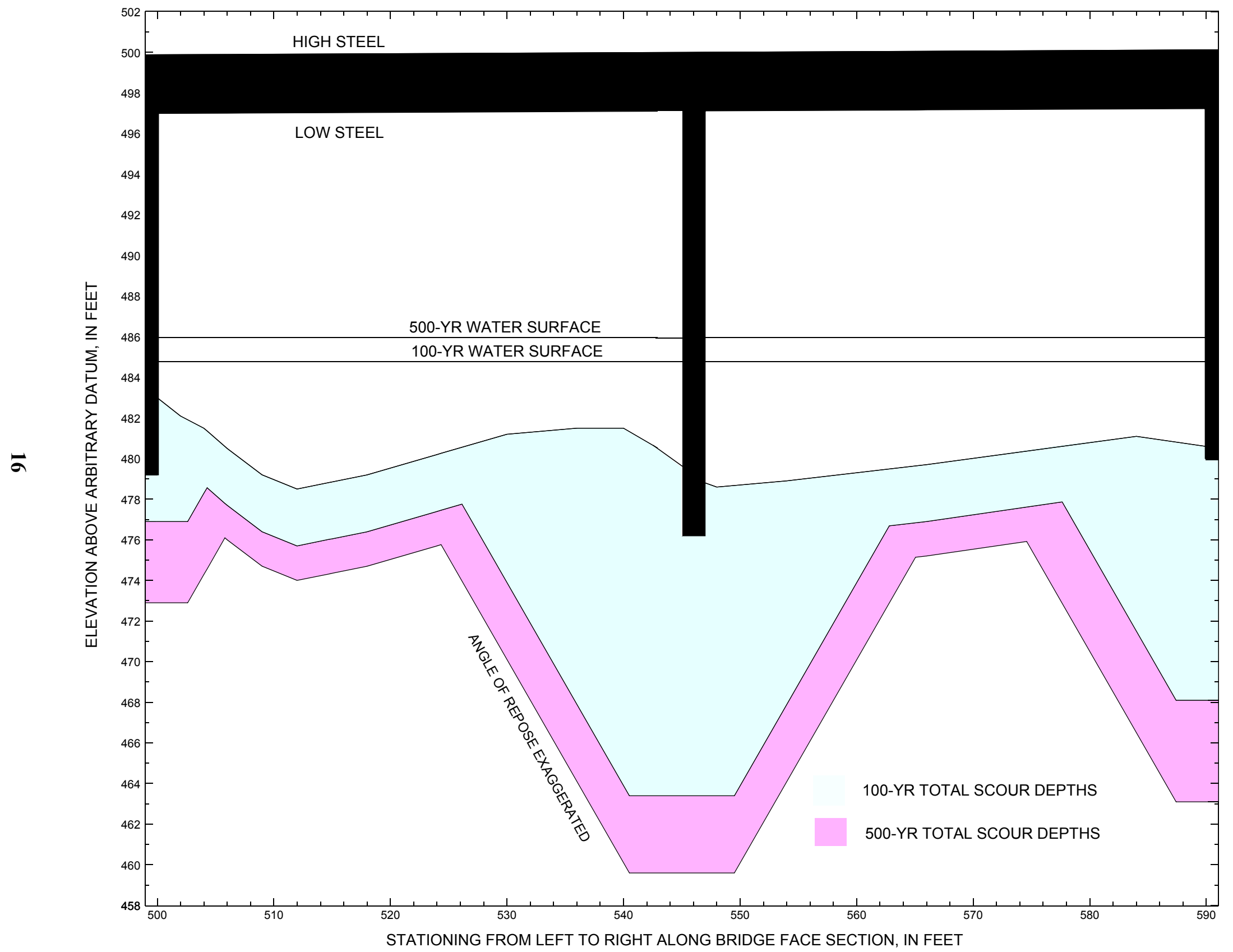

Figure 8. Scour elevations for the 100-yr and 500-yr discharges at structure NORWTH00030046 on town highway 3, crossing the Ompompanoosuc River, Norwich, Vermont. 
Table 1. Remaining footing/pile depth at abutments for the 100-year discharge at structure NORWTH00030046 on Town Highway 3, crossing the Ompompanoosuc River, Norwich, Vermont.

[VTAOT, Vermont Agency of Transportation; --,no data]

\begin{tabular}{|c|c|c|c|c|c|c|c|c|c|c|c|}
\hline Description & Station $^{1}$ & $\begin{array}{l}\text { VTAOT } \\
\text { minimum } \\
\text { low-chord } \\
\text { elevation } \\
\text { (feet) }\end{array}$ & $\begin{array}{c}\text { Surveyed } \\
\text { minimum } \\
\text { low-chord } \\
\text { elevation } \\
\text { (feet) }\end{array}$ & $\begin{array}{c}\text { Bottom of } \\
\text { footing } \\
\text { elevation } \\
\text { (feet) }\end{array}$ & $\begin{array}{c}\text { Channel } \\
\text { elevation at } \\
\text { abutment/ } \\
\text { pier }^{2} \\
\text { (feet) }\end{array}$ & $\begin{array}{l}\text { Contraction } \\
\text { scour depth } \\
\text { (feet) }\end{array}$ & $\begin{array}{l}\text { Abutment } \\
\text { scour } \\
\text { depth } \\
\text { (feet) }\end{array}$ & $\begin{array}{l}\text { Pier } \\
\text { scour } \\
\text { depth } \\
\text { (feet) }\end{array}$ & $\begin{array}{l}\text { Depth of } \\
\text { total scour } \\
\text { (feet) }\end{array}$ & $\begin{array}{c}\text { Elevation of } \\
\text { scour }^{2} \\
\text { (feet) }\end{array}$ & $\begin{array}{c}\text { Remaining } \\
\text { footing/pile } \\
\text { depth } \\
\text { (feet) }\end{array}$ \\
\hline \multicolumn{12}{|c|}{100 -yr. discharge is 2,600 cubic-feet per second } \\
\hline Left abutment & 500 & 395.9 & 497.0 & 479.2 & 483.0 & 2.8 & 3.3 & -- & 6.1 & 476.9 & -2.3 \\
\hline Pier & 545 & 395.9 & 497.3 & 476.2 & 479.2 & 2.8 & -- & 13.0 & 15.8 & 463.4 & -12.8 \\
\hline Right abutment & 590 & 395.9 & 497.1 & 480.0 & 480.6 & 2.8 & 9.7 & -- & 12.5 & 468.1 & -11.9 \\
\hline
\end{tabular}

1. Measured along the face of the most constricting side of the bridge.
${ }^{2}$ Arbitrary datum for this study.

Table 2. Remaining footing/pile depth at abutments for the 500-year discharge at structure NORWTH00030046 on Town Highway 3, crossing the Ompompanoosuc River, Norwich, Vermont.

[VTAOT, Vermont Agency of Transportation; --, no data]

\begin{tabular}{|c|c|c|c|c|c|c|c|c|c|c|c|}
\hline Description & Station ${ }^{1}$ & $\begin{array}{l}\text { VTAOT } \\
\text { minimum } \\
\text { low-chord } \\
\text { elevation } \\
\text { (feet) }\end{array}$ & $\begin{array}{c}\text { Surveyed } \\
\text { minimum } \\
\text { low-chord } \\
\text { elevation } \\
\text { (feet) }\end{array}$ & $\begin{array}{c}\text { Bottom of } \\
\text { footing } \\
\text { elevation } \\
\text { (feet) }\end{array}$ & $\begin{array}{c}\text { Channel } \\
\text { elevation at } \\
\text { abutment/ } \\
\text { pier }^{2} \\
\text { (feet) }\end{array}$ & $\begin{array}{l}\text { Contraction } \\
\text { scour depth } \\
\text { (feet) }\end{array}$ & $\begin{array}{l}\text { Abutment } \\
\text { scour } \\
\text { depth } \\
\text { (feet) }\end{array}$ & $\begin{array}{l}\text { Pier } \\
\text { scour } \\
\text { depth } \\
\text { (feet) }\end{array}$ & $\begin{array}{l}\text { Depth of } \\
\text { total scour } \\
\text { (feet) }\end{array}$ & $\begin{array}{c}\text { Elevation of } \\
\text { scour }^{2} \\
\text { (feet) }\end{array}$ & $\begin{array}{c}\text { Remaining } \\
\text { footing/pile } \\
\text { depth } \\
\text { (feet) }\end{array}$ \\
\hline \multicolumn{12}{|c|}{500 -yr. discharge is 4,420 cubic-feet per second } \\
\hline Left abutment & 500 & 395.9 & 497.0 & 479.2 & 483.0 & 4.5 & 5.6 & -- & 10.1 & 472.9 & -6.3 \\
\hline Pier & 545 & 395.9 & 497.3 & 476.2 & 479.2 & 4.5 & -- & 15.1 & 19.6 & 459.6 & -16.6 \\
\hline Right abutment & 590 & 395.9 & 497.1 & 480.0 & 480.6 & 4.5 & 13.0 & -- & 17.5 & 463.1 & -16.9 \\
\hline
\end{tabular}

1. Measured along the face of the most constricting side of the bridge.

2. Arbitrary datum for this study. 


\section{SELECTED REFERENCES}

Arcement, G.J., Jr., and Schneider, V.R., 1989, Guide for selecting Manning's roughness coefficients for natural channels and flood plains: U.S. Geological Survey Water-Supply Paper 2339, 38 p.

Barnes, H.H., Jr., 1967, Roughness characteristics of natural channels: U.S. Geological Survey Water-Supply Paper 1849, 213 p.

Brown, S.A. and Clyde, E.S., 1989, Design of riprap revetment: Federal Highway Administration Hydraulic Engineering Circular No. 11, Publication FHWA-IP-89-016, 156 p.

Federal Emergency Management Agency, 1988, Flood Insurance Study, Town of Norwich, Windsor County, Vermont, Washington, D.C., June 15, 1988.

Froehlich, D.C., 1989, Local scour at bridge abutments in Ports, M.A., ed., Hydraulic Engineering--Proceedings of the 1989 National Conference on Hydraulic Engineering: New York, American Society of Civil Engineers, p. 13-18.

Hayes, D.C.,1993, Site selection and collection of bridge-scour data in Delaware, Maryland, and Virginia: U.S. Geological Survey Water-Resources Investigation Report 93-4017, 23 p.

Interagency Advisory Committee on Water Data, 1982, Guidelines for determining flood flow frequency: U.S. Geological Survey, Bulletin 17B of the Hydrology Subcommittee, $190 \mathrm{p}$.

Laursen, E.M., 1960, Scour at bridge crossings: Journal of the Hydraulics Division, American Society of Civil Engineers, v. 86, no. HY2, p. 39-53.

Richardson, E.V., Harrison, L.J., Richardson, J.R., and Davis, S.R., 1993, Evaluating scour at bridges: Federal Highway Administration Hydraulic Engineering Circular No. 18, Publication FHWA-IP-90-017, 131 p.

Richardson, E.V., Simons, D.B., and Julien, P.Y., 1990, Highways in the river environment: Federal Highway Administration Publication FHWA-HI-90-016.

Ritter, D.F., 1984, Process Geomorphology: W.C. Brown Co., Debuque, Iowa, 603 p.

Shearman, J.O., 1990, User's manual for WSPRO--a computer model for water surface profile computations: Federal Highway Administration Publication FHWA-IP-89-027, 187 p.

Shearman, J.O., Kirby, W.H., Schneider, V.R., and Flippo, H.N., 1986, Bridge waterways analysis model; research report: Federal Highway Administration Publication FHWA-RD-86-108, 112 p.

U.S. Department of Transportation, 1993, Stream stability and scour at highway bridges, Participant Workbook: Federal Highway Administration Publication FHWA HI-91-011.

U.S. Geological Survey, 1981, Lyme, N.H.-VT., 7.5 Minute Series quadrangle map: U.S. Geological Survey Topographic Maps, Scale 1:24,000. 


\section{APPENDIX A: \\ WSPRO INPUT FILE}




\section{WSPRO INPUT FILE}

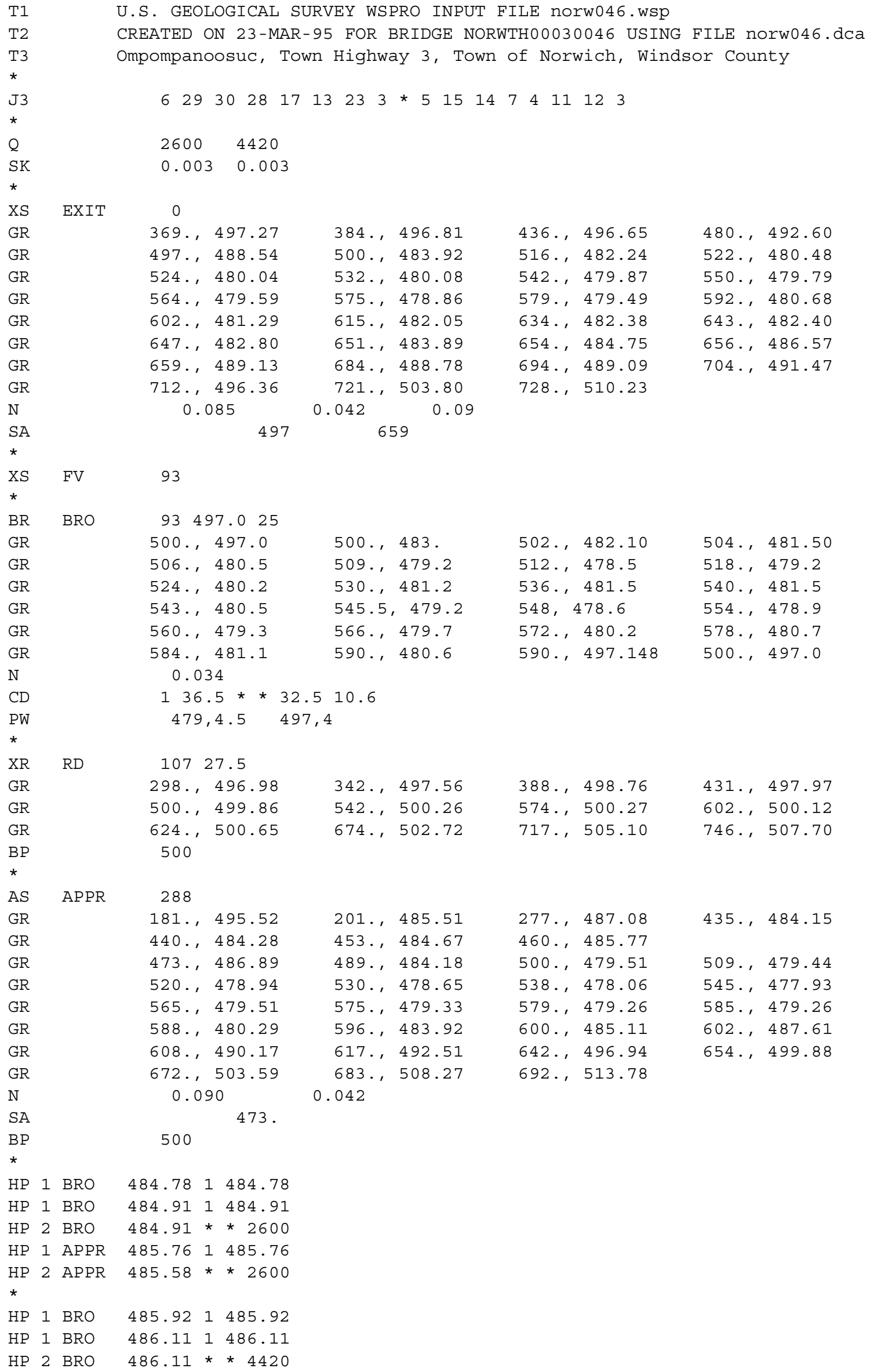




\section{APPENDIX B: \\ WSPRO OUTPUT FILE}




\section{WSPRO OUTPUT FILE}

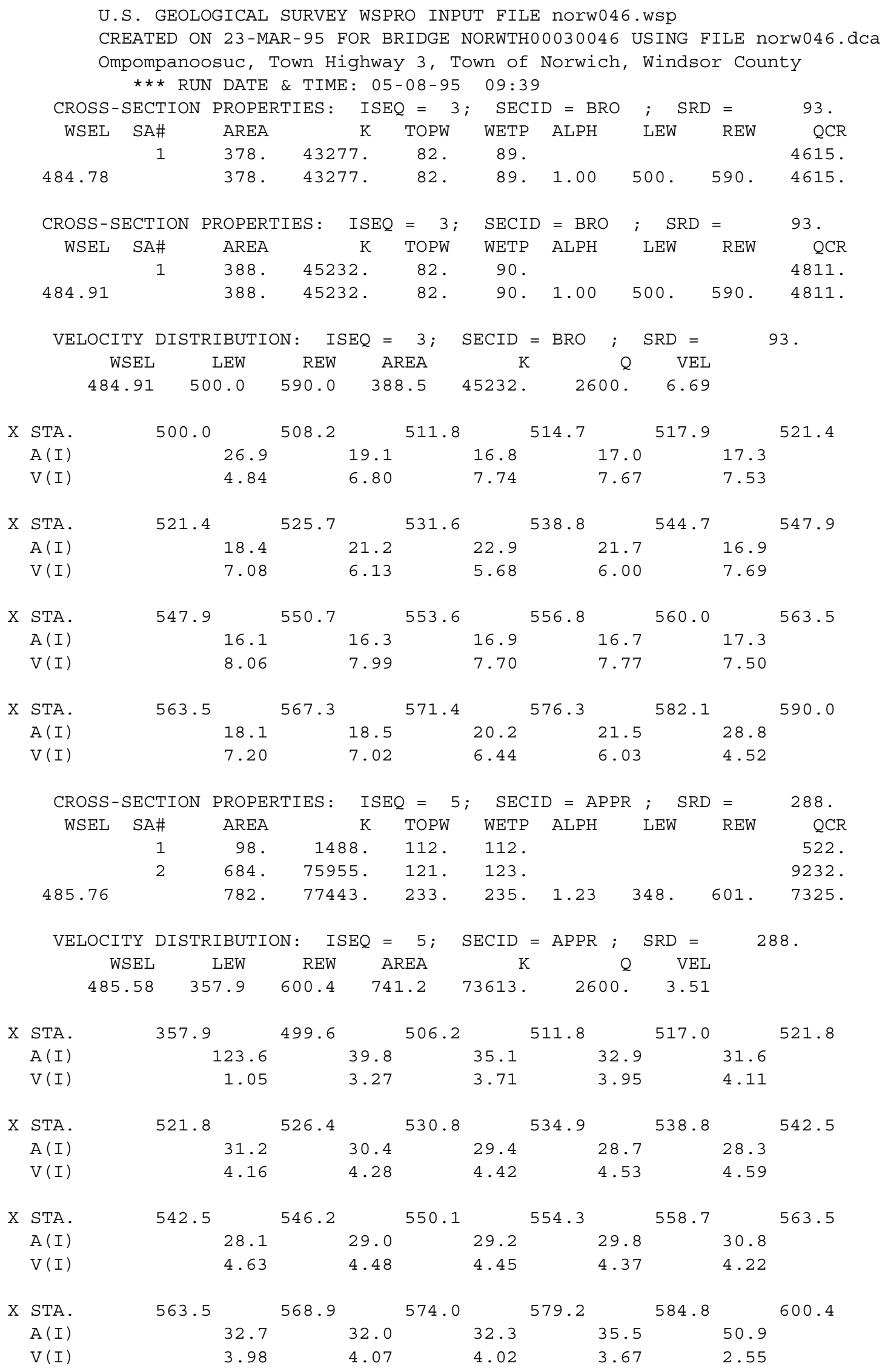




\section{WSPRO OUTPUT FILE (continued)}

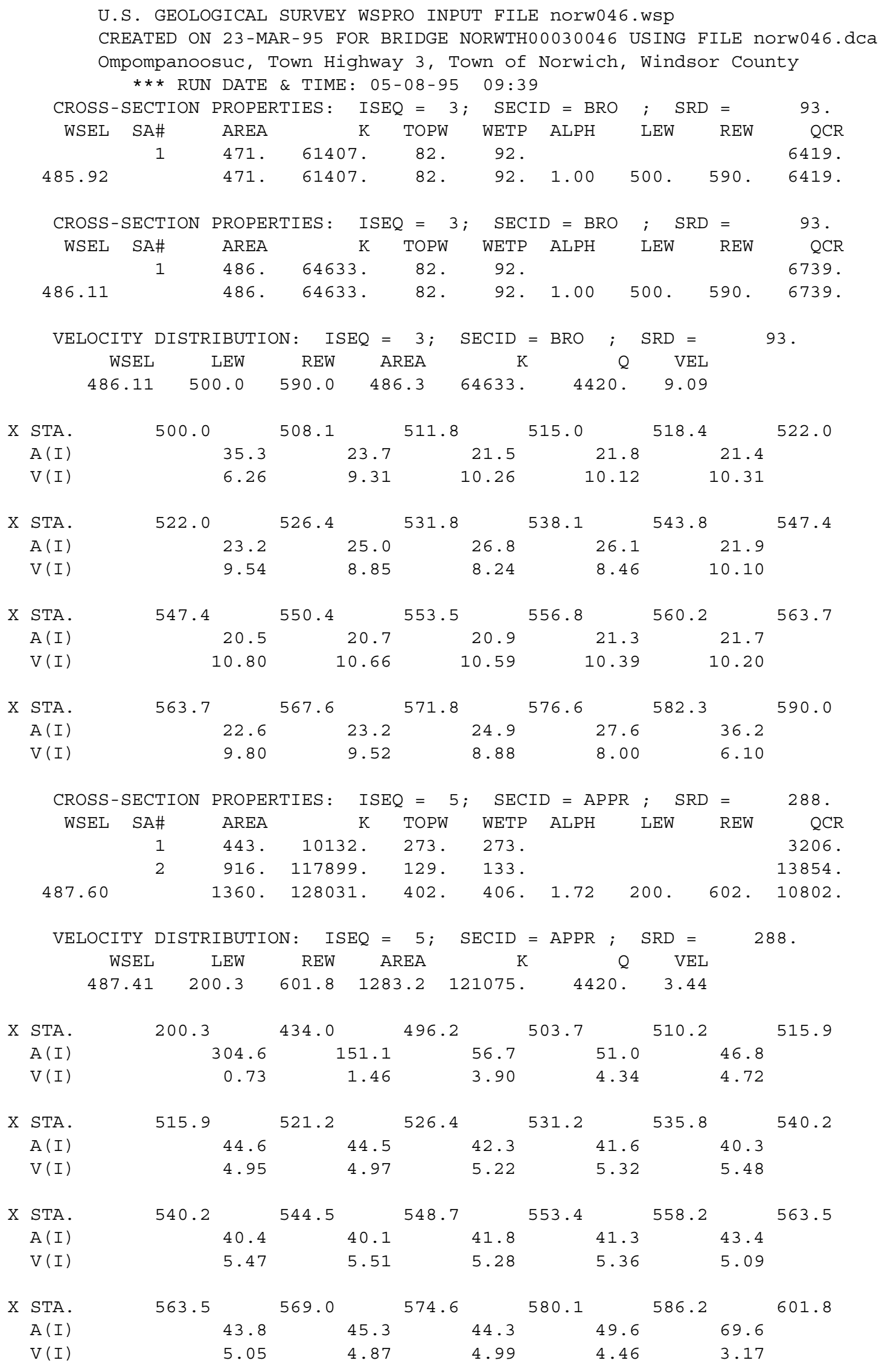

U.S. GEOLOGICAL SURVEY WSPRO INPUT FILE nOIW046.wsp

CREATED ON 23-MAR-95 FOR BRIDGE NORWTH00030046 USING FILE norw046.dCa mpompanoosuc, Town Highway 3, Town of Norwich, Windsor County CROSS-SECTION PROPERTIES: ISEQ $=3 ;$ SECID $=$ BRO ; SRD $=93$ $\begin{array}{llllll}1 & 471.61407 .62 .62 . & 82.619 .\end{array}$ CROSS-SECTION PROPERTIES: ISEQ $=3 ;$ SECID $=$ BRO ; $\quad$ SRD $=93$. $\begin{array}{llllll}1 & 486 . & 64633 . & 82 . & 92 . & 6739 .\end{array}$ 


\title{
WSPRO OUTPUT FILE (continued)
}

\author{
U.S. GEOLOGICAL SURVEY WSPRO INPUT FILE nOIW046.wsp \\ CREATED ON 23-MAR-95 FOR BRIDGE NORWTH00030046 USING FILE norw046.dCa \\ Ompompanoosuc, Town Highway 3, Town of Norwich, Windsor County \\ *** RUN DATE \& TIME: 05-08-95 09:39

\begin{tabular}{|c|c|c|c|c|c|c|c|c|c|c|}
\hline \multicolumn{2}{|c|}{ XSID: CODE } & SRDL & LEW & AREA & VHD & $\mathrm{HF}$ & EGL & CRWS & Q & WSEL \\
\hline & SRD & FLEN & REW & $\mathrm{K}$ & ALPH & $\mathrm{HO}$ & ERR & FR\# & VEL & \\
\hline EXIT & :XS & $\star \star \star \star * \star *$ & 499. & 566. & 0.33 & $\star * * * *$ & 485.13 & 483.07 & 2600 . & 484.80 \\
\hline & 0 . & $\star \star * \star * \star *$ & 654. & 47461 & 1.00 & $\star * * * *$ & $\star \star \star * \star * \star * *$ & 0.42 & 4.59 & \\
\hline FV & :FV & 93. & 499. & 613. & 0.28 & 0.25 & 485.38 & $\star \star \star \star \star \star * \star *$ & 2600 . & 485.10 \\
\hline & 93. & 93. & 654. & 53943. & 1.00 & 0.00 & 0.01 & 0.38 & 4.24 & \\
\hline & $<$ & $<<\mathrm{THE}$ & BOVE & SULTS R & ELECT & "NORMA & $\mathrm{L}^{\prime \prime} \quad$ (UNC & (NSTRICTED) & FLOW> & $>=$ \\
\hline
\end{tabular}




\title{
WSPRO OUTPUT FILE (continued)
}

\author{
U.S. GEOLOGICAL SURVEY WSPRO INPUT FILE nOIW046.wsp \\ CREATED ON 23-MAR-95 FOR BRIDGE NORWTH00030046 USING FILE norw046.dca \\ Ompompanoosuc, Town Highway 3, Town of Norwich, Windsor County \\ *** RUN DATE \& TIME: 05-08-95 09:39

\begin{tabular}{|c|c|c|c|c|c|c|c|c|c|c|}
\hline \multicolumn{2}{|c|}{ XSID : CODE } & SRDL & LEW & AREA & VHD & $\mathrm{HF}$ & EGL & CRWS & Q & WSEL \\
\hline & $\mathrm{SRD}$ & FLEN & REW & K & ALPH & $\mathrm{HO}$ & ERR & FR\# & VEL & \\
\hline \multirow[t]{2}{*}{ EXIT } & $: X S$ & 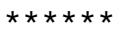 & 499. & 786. & 0.49 & $* * * * *$ & 486.70 & 484.06 & 4420 & 486.21 \\
\hline & 0 . & 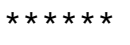 & 656 & 80664 & 1.00 & $\star * \star * *$ & $\star \star \star \star \star \star * \star *$ & 0.44 & 5.62 & \\
\hline \multirow[t]{2}{*}{ FV } & $: F V$ & 93. & 498. & 836. & 0.44 & 0.25 & 486.96 & 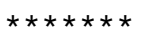 & 4420 . & 486.53 \\
\hline & 93. & 93. & 656. & 89020 . & 1.00 & 0.00 & 0.01 & 0.41 & 5.29 & \\
\hline
\end{tabular} \\ SECOND USER DEFINED TABLE.

\begin{tabular}{llrrrrrrrr} 
XSID : CODE & Q & CRWS & FR\# & EGL & VHD & HF & HO & WSEL \\
EXIT & $:$ XS & 4420. & 484.06 & 0.44 & 486.70 & $0.49 * * * * * * * * * * *$ & 486.21 \\
FV & $: F V$ & $4420 . * * * * * * * *$ & 0.41 & 486.96 & 0.44 & 0.25 & 0.00 & 486.53 \\
BRO & $:$ BR & 4420. & 484.90 & 0.69 & 487.29 & 1.37 & 0.37 & 0.22 & 485.92 \\
RD & $:$ RG & \multicolumn{2}{c}{$0 . * * * * * * * * * * * * * * * * * * * * * * * * * * * * * * * * * * * * * * * * * * * * * * * * * *$} \\
APPR & $:$ AS & 4420. & 483.18 & 0.41 & 487.88 & 0.28 & 0.41 & 0.19 & 487.60
\end{tabular}




\section{APPENDIX C:}

\section{BED-MATERIAL PARTICAL-SIZE DISTRIBUTION}




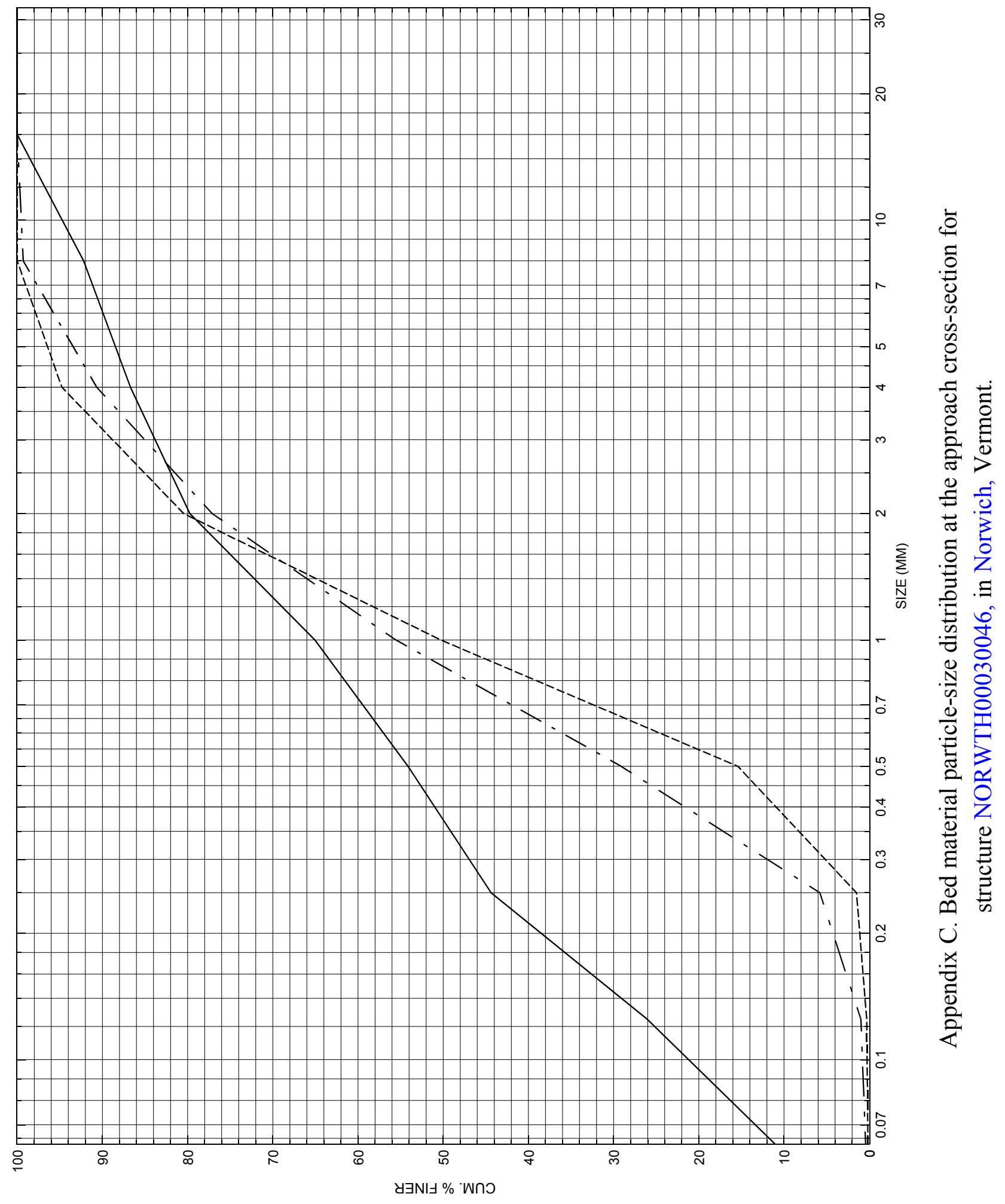




\section{APPENDIX D: \\ HISTORICAL DATA FORM}

